\title{
A Scientometric analysis of landslides research in the western branch of East African Rift (DR Congo)
}

\author{
Ngulwe Tumaini wa Rusaati ${ }^{1 *}$, Butoto Imani wa Rusaati ${ }^{2,3}$, Pacifique Kiza Rusati ${ }^{4}$ \\ ${ }^{1}$ Ecole du Cinquantenaire, Goma, Democratic Republic of Congo \\ ${ }^{2}$ School of Forest Sciences and Land Architecture, College of Agriculture and Life Sciences, Kyungpook \\ National University, Daegu 41566, Republic of Korea \\ ${ }^{3}$ Natural Sciences Research Center (CRSN/Lwiro), DS Bukavu, Democratic Republic of Congo \\ ${ }^{4}$ Jangmin E\&C, Seoul 05839, Republic of Korea.
}

\begin{abstract}
The Albertine Rift, which is part of the East African Rift, is a region prone to repetitive slope instability due to its intense rainfall, high weathering rate, and consistent seismic activities. Although this has led to several publications about landslides in the past. Unfortunately, not many attempts at gathering systematic data on landslide research in the western Albertine rift have been made so far. This study analyses the research carried out in landslides in Albertine rift during 2003-2019 on several parameters including: the title, authors, institutions, publication year, keywords, the names of journals publishing the articles, and language. The majority of papers were written in French (62\%). Geo-Eco-Trop journal has published the greatest number of papers (46\%). The majority of authors (67\%) produced only one paper. Moreover, Moeyersons had the highest co-authorship connections (15), followed by Dille, Trefois, and Nobil with 14, 10, and 7 connections respectively. 13 institutions from 6 countries contributing to the researches. The most producing institutions were Royal Museum for Central Africa, followed by the "Universite Officielle de Bukavu". 49 Keywords were used, among which, 43 (88\%) appeared only once and $6(12 \%)$ appeared twice. The most frequently occurring words are landslides and the tropical environment.
\end{abstract}

Keywords: Landslides, Scientometric Analysis, Western African Rift, DR Congo.

\section{INTRODUCTION}

Landslides describe the downward movement of masses such as soil, rock, artificial fill, or a combination of them, under the effect of gravity acting on a weakened rock and soil composing a sloping region [1], [2]. There are natural hazard causing great loss of life and destruction of infrastructure, and environmental degradation [3-8] [10].

These phenomena mostly occur in regions with steep slopes and remote areas, such as mountainous areas. Their occurrence frequency can be higher since they are caused by many factors, including natural and geological events such as rainfall, flood, and earthquakes, and anthropogenic factors such as deforestation and urbanism [9], [11], [12].

Corominas et al. [13] reported that most less developed countries are more vulnerable to landslides, and particularly in tropical regions where a combination of some factors such as rainfall intensity, tectonics activities, lithology, and population density are recurrent. Nevertheless, little knowledge induced by landslides, related risk and hazards, lack of appropriate research resources, and investment in less developed countries contribute to making landslides events a great threat to people's lives; their social and economic aspects in these regions.

The East African Rift is also part of the tropical region prone to repetitive slope instability due to its rainy climate, topography, and weathering rates [6], [14]. Especially the Albertine Rift, which is the western branch of the East African Rift and part of the Eastern region of the Democratic Republic of the Congo (DRC) does not escape from this reality. This region is well known for its high-density population, intense rainfall, and consistent seismic and volcanic activities [15], [16]. Some researches on landslides in the Albertine Rift region have been conducted in the past decades. However, although scientometric or bibliometric 
analyses have been applied to natural hazards around the world [17-19], not many attempts at gathering systematic data on landslide research in the western Albertine Rift have been made so far. Thus, a comprehensive analysis is necessary and will help orient upcoming studies in the field.

Scientometrics are a quantitative study which measure and analyze literature within a specific scientific field and serve as a vital basis for defining and debating a future research plan [20], [21]. The major indicator of scientific progress is the distribution of publications over a period, the country's contribution, the collaboration pattern among the scientists, national and international collaboration, etc. [22].

Hence, the main objective of this research is to examine the scientific contribution in landslide research during the last 17 years (from 2003 to 2019) in terms of publication output about landslides in the western Albertine Rift. Especially, this research aims to: (1) measure the research productivity, (2) study which are national and foreign institutions (universities, research centers) contribution, (3) determine which country contributed to landslide's study; (4) find in which journal studies have been published, (5) and to see which language is most used in landslide's publication.

\section{METHODOLOGY}

This study focuses on articles that address issues about landslides in the western Albertine rift in DR Congo. The papers published during the 2003-2019 timeframe were searched using available internet search engines such as Google, Bing, and Yahoo, using the keywords "landslide, Albertine Rift, and D.R Congo". Article details, including the title, authors, institutions, publication year, keywords, the names of journals publishing the articles, and language were collected. Motivated by the goal to discover the extent to which landslide researches in the Albertine rift region is going, we are interested to find out which institutions are working in this field, and also if there has been researching collaboration within institutions or beyond institutions or countries. The preliminary results were exported in Microsoft Excel, which was used later for scientometric analysis. The frequency of each keyword was counted and a graphical mapping of the keywords was developed using $\mathrm{R}$ software. The initial search generated about 23 papers, but only 13 papers met our research criteria and were selected for analysis (Appendix 1). After data processing, 49 keywords from the 13 articles were found.

\section{RESULTS}

\subsection{Timeframe of Publication}

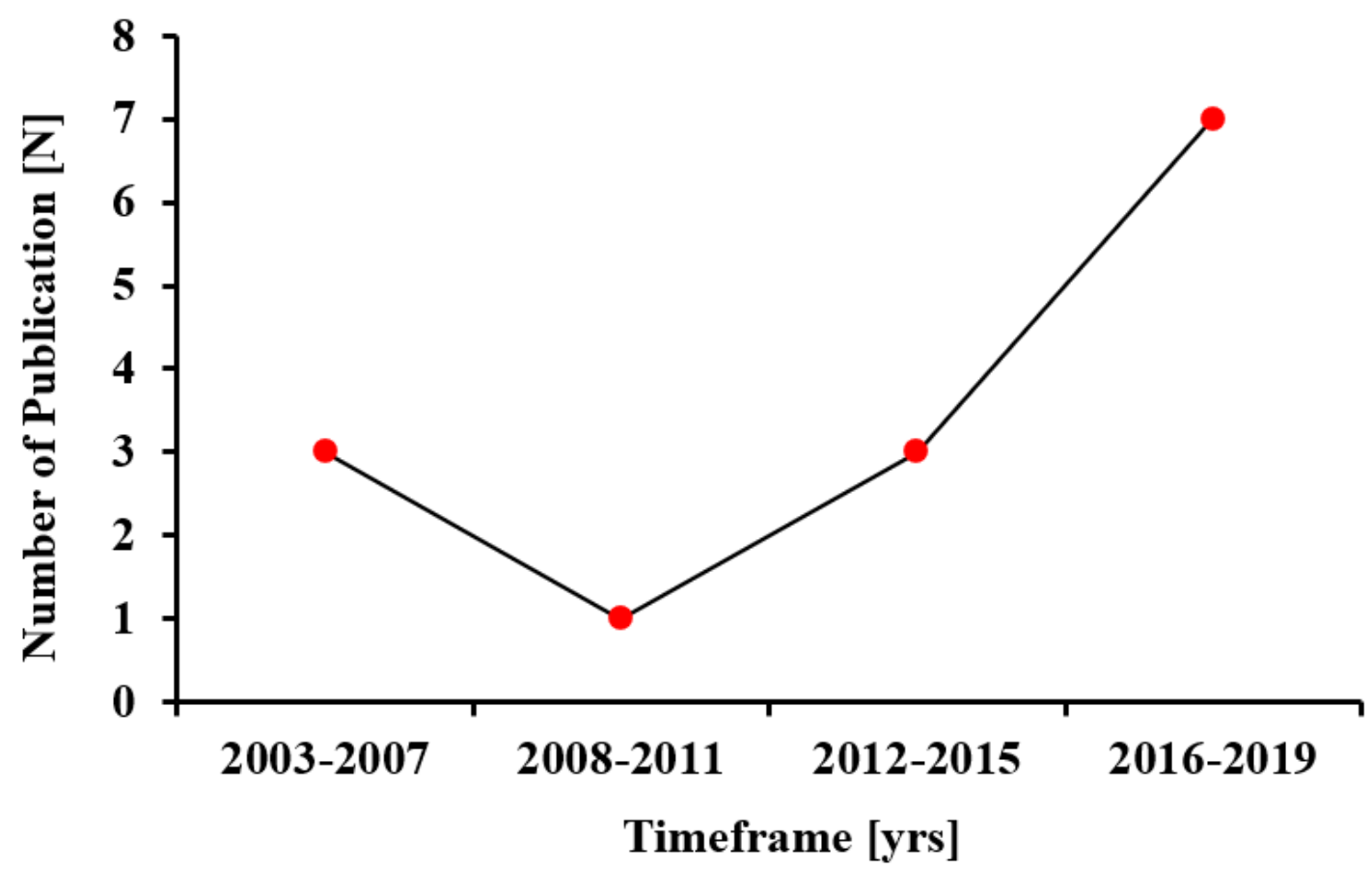

Figure 1. Timeframe of western Albertine Rift landslides-publications in timeframe 
As illustrated in Figure 1, data analysis of publications shows that about half of the publications were published between 2016 and $2019(54 \%, \mathrm{~N}=7)$ while the other half were published between 2003 to $2015(46 \%, \mathrm{~N}=6) .2017$ was characterized by a high number $(31 \%, \mathrm{~N}=4)$ of published papers. Moreover, while 6 years $(2006,2007,2009,2014,2018$, and 2019) have only a single publication, no publication is found during 8 years $(2004,2005,2008,2010,2011,2012$, 2013, and 2016). From this trend, it is observed that much effort is being made in terms of increasing research publications addressing issues of landslides in this given region.

\subsection{Publication Pattern}

Our investigation has found that research about landslides in the western Albertine Rift during the past 17 years was published in 7 journals (Table 1). Approximately $46 \%$ of the articles were published in Geo-Eco-Trop, followed by the International Journal of Innovation and Scientific Research (15\%); the other 5 journals were found to have 1 publication each. Most of the papers were written in French (about 62\%; $\mathrm{N}=8$ ), and 38\% ( $=5$ ) were published in English. This is due to the French language being used as an official and medium language of study in DR Congo.

Table 1. Preferred Journals

\begin{tabular}{lcc}
\hline Journal & No. of paper [ N] & Language \\
\hline Geo-Eco-Trop & 6 & French \\
$\begin{array}{l}\text { International Journal of Innovation and Scientific } \\
\text { Research }\end{array}$ & 2 & French \\
Geomorphology & & \\
Remote sensing & 1 & English \\
Nat Hazards & 1 & English \\
Geological Society & 1 & English \\
Engineering Geology & 1 & English \\
\hline
\end{tabular}

\subsection{Authorships and institutions collaboration}

Table 2 shows the frequency distribution of author productivity in the field of landslides in the western Albertine Rift. Of the 46 authors' names, 31 produced only one article; 14 produced two articles. The number of authors who produced more than 6 articles is small (only 1.9\%). Figure 2 displays the coauthor network maps based on detailed data derived from R-Software. In this network, central authors are the ones who are most connected to other authors in the network. ${ }^{[23]}$ From Figure 2, it is observed that Moeyersons had the highest co-authorship connections (15), followed by Dille, Trefois, and Nobil with 14, 10, and 7 connections respectively.

Table 2. Distribution of authors and their publications

\begin{tabular}{cc}
\hline No. of paper [ N] & No. of authors \\
\hline $\mathbf{1}$ & 31 \\
$\mathbf{2}$ & 14 \\
$\mathbf{4}$ & 3 \\
$\mathbf{8}$ & 2 \\
Total & 1 \\
\hline
\end{tabular}




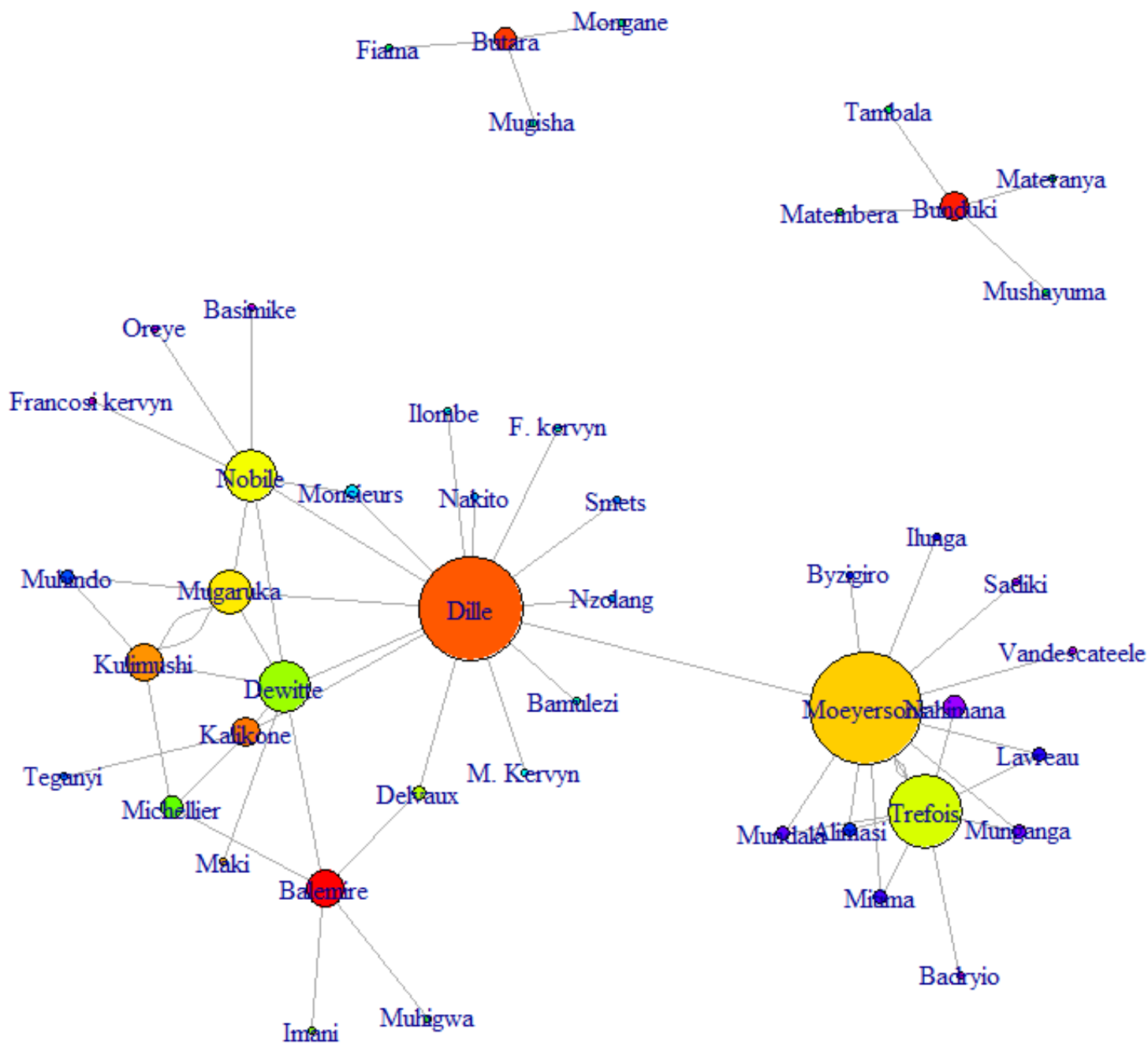

Figure 2 Authors' network and co-authorship

From an authors' institution perspective, active international collaboration was observed with 13 institutions contributing to the research (Table 3), among which 5 institutions were from DR Congo and 8 institutions from other countries from other 6 countries (Table 4). Out of 13 articles, 14\% were published by a single institution, and others were inter- institutional collaborative papers, either national or international. Scientists from Belgium make the most contributions, authoring or coauthoring about $79 \%$ of the articles. The majority of papers was authored or coauthored by researchers from the Royal Museum for Central Africa, contributing in 10, followed by the "Université Officielle de Bukavu" and "Centre de Recherche en Sciences Naturelles/Lwiro" with 9 and 4 papers, respectively (Table 3). To explore patterns of institutional collaboration, we used R software to map the co-authorship networks of active institutions in landslides article production in the western Albertine Rift (Figure 3). The size of the nodes indicates the degree of collaboration. Of the 13 institutions, The Royal Museum for Central Africa is the most active institution for collaboration, just before The Universite Officielle de Bukavu. 
International Journal of Advances in Scientific Research and Engineering (ijasre), Vol 7 (11), November -2021

Table 3. Institution's contribution

\begin{tabular}{lc}
\hline Contributing Institution name & No. of paper [ N] \\
\hline Royal Museum for Central Africa & 10 \\
Université Officielle de Bukavu (ex centre universitaire de Bukavu) & 9 \\
Centre de Recherche en Sciences Naturelles /Lwiro & 4 \\
University of Burundi & 3 \\
Centre des Recherches Géologiques et Minières, Station Provincial/ & 3 \\
Lwiro & \\
Kigali Institute of Education & 2 \\
Vrije Universiteit Brussel & 2 \\
University of Liège & 2 \\
Fonds de la Recherche Scientifique - FNRS & 2 \\
Institut Supérieur Pédagogique de Bukavu, & 2 \\
National Museum of Natural History & 1 \\
European Center for Geodynamics and Seismology & 1 \\
Université Catholique du Graben & 1 \\
\hline
\end{tabular}

Table 4. Number of institutions per country

\begin{tabular}{lc}
\hline Countries & No. of institution \\
\hline DR Congo & 5 \\
Belgium & 4 \\
Burundi & 1 \\
Rwanda & 1 \\
USA & 1 \\
Luxembourg & 1 \\
\hline
\end{tabular}




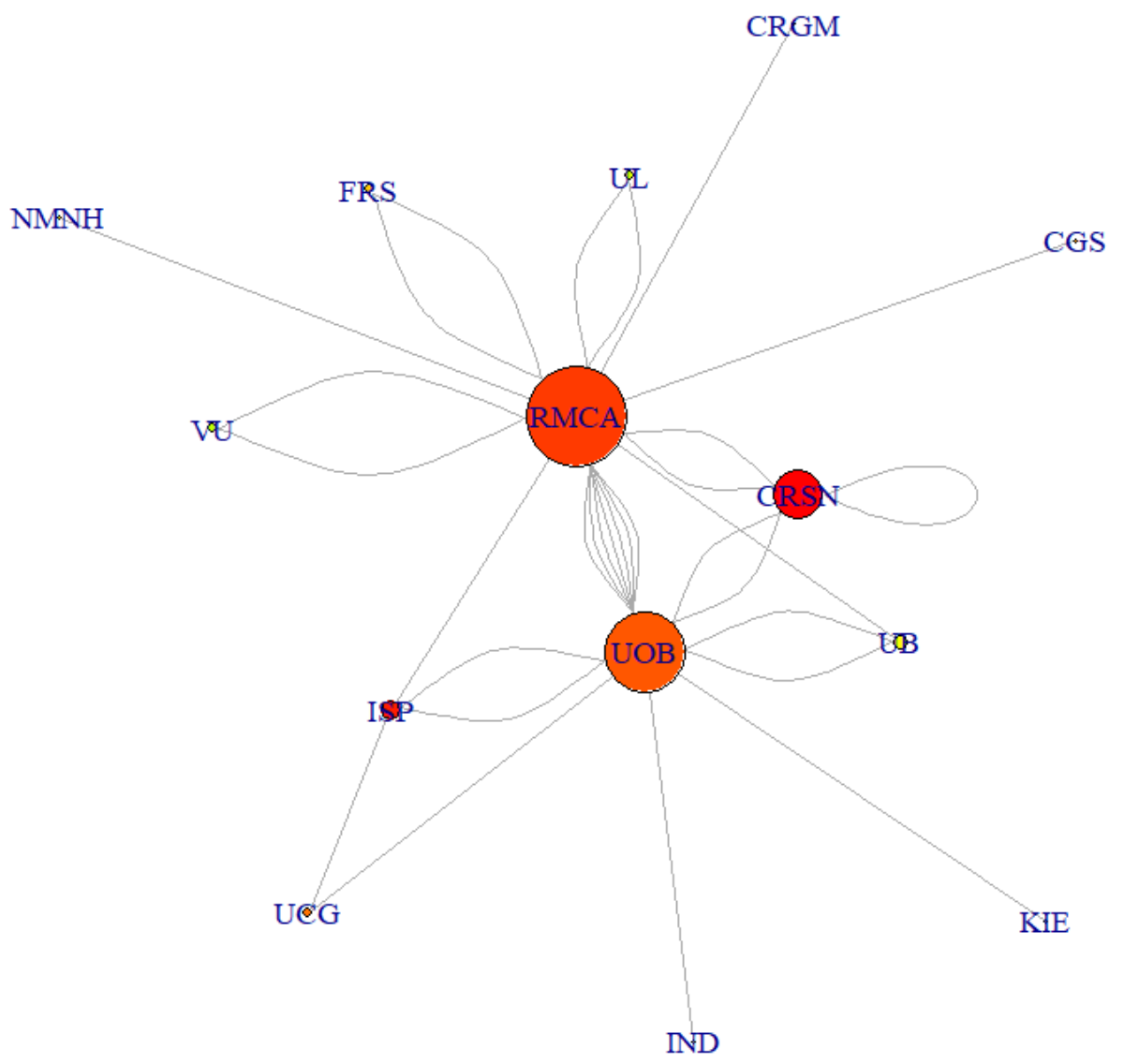

Figure 3. Network of institutions collaboration

Legend: $\mathrm{VU}=$ vrije university; $\mathrm{RMCA}=$ Royal Museum for Cental Africa; $\mathrm{CRSN}=$ Centre de Recherches en Sciences Naturelles/Lwiro; UB= University of Burundi; UL=University of Liege; ISP= Institut Supérieur Pédagogique de Bukavu; KIE= Kigali institute of Education; $\mathrm{CGS}=$; FRS=; NMNH=; UCG=Université Catholique de Graben; $\mathrm{CRGM=} \mathrm{Centre} \mathrm{de} \mathrm{Recherches}$ Géologiques et Minières; UOB=Université Officielle de Bukavu; IND= independent researcher. Node size is proportional to the collaborations.

\subsection{Keywords and keyword cluster}

The keywords are the high-level summarization and refinement of the article core [24], [25]. Examination of keywords in these articles revealed that 49 Keywords were used, among which, 43 (88\%) appeared only once and $6(12 \%)$ appeared twice. The most frequently occurring words are landslides (7 times), and the tropical environment (3 times) (Figure 4). 


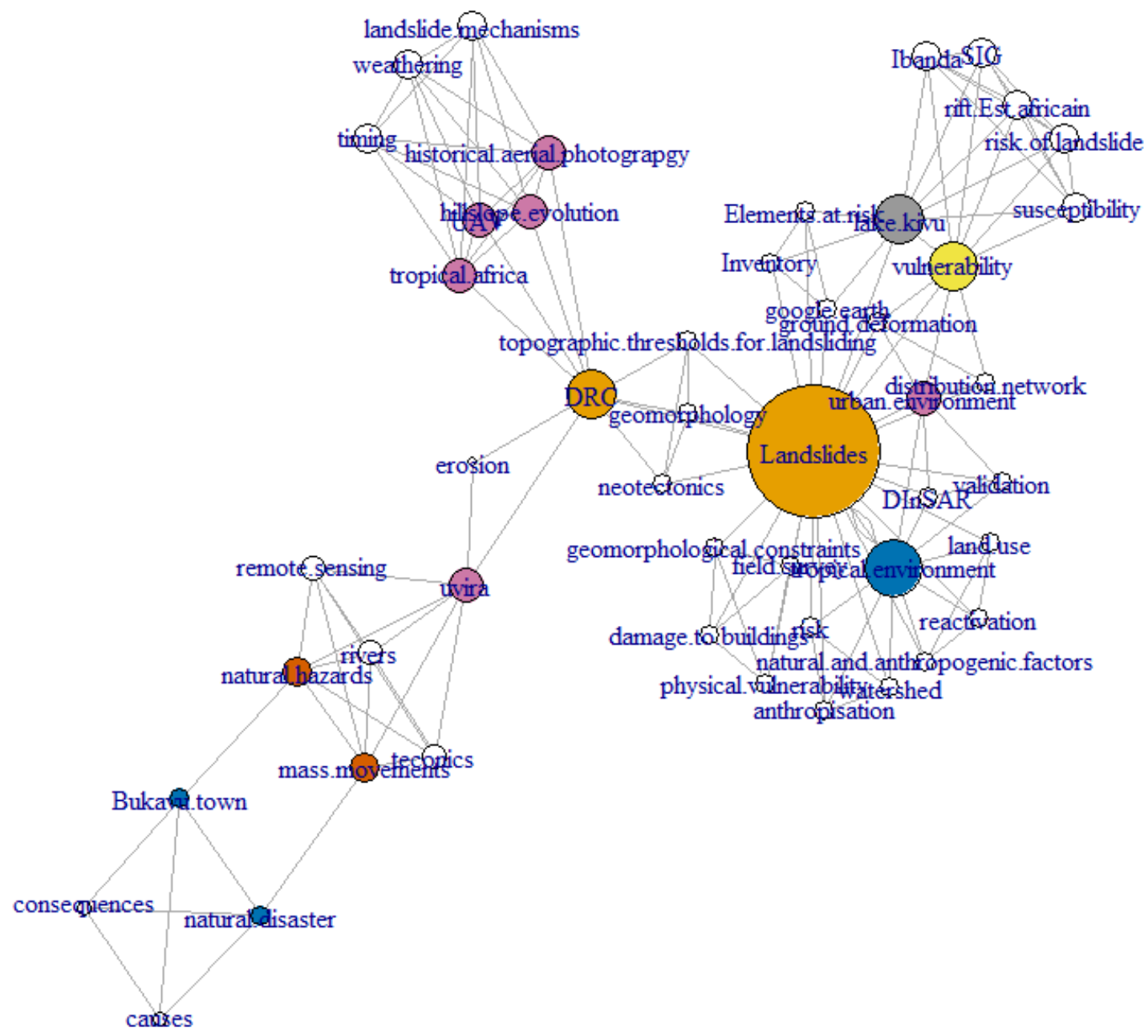

Figure 4. Network of keywords co-occurrence. Node size is proportional to cited time.

\section{CONCLUSION}

In this study, a comprehensive scientometric analysis of landslides literature related to the western Albertine Rift was conducted to determine the research productivity, institutions contribution, frequently cited journals, and keywords. The study examines the scientific contribution in landslide research during the last 17 years (from 2003 to 2019) in terms of publications to determine the research productivity, institutions contribution, frequently cited journals, and keywords. The results indicate that about half of the publications were published in the last 4 years (2016-2019), while the other half were published from 2003 to 2015. Among the 7 journals in which papers were published, Geo-Eco-Trop has published about $46 \%$ of the papers, followed by the International Journal of Innovation and Scientific Research (15\%). From an authorship perspective, multi-authorship is observed, with 3 authors having a connected network of more than 10 authors, and the smallest network having 4 authors connected. Although the western Albertine Rift is located in DR Congo, 14 institutions, both nationals, and internationals, have contributed to the productivity, coming from 4 countries in addition to DR Congo. Examination of keywords in these articles has revealed that 49 Keywords were used, among which, $88 \%$ appeared only once and $12 \%$ appeared twice. The most frequently occurring words are landslide ( 7 times), and the tropical environment ( 3 times). This systematic evaluation provides an overview of the literature about landslides in the western Albertine Rift to researchers and professionals. Thus, research results may be necessary and helpful for orienting upcoming studies in the field.

\section{ACKNOWLEDGEMENT}

The authors would like to thank all of the scholars whose work contributed to this scientometric analysis.

\section{CONFLICT OF INTEREST}

The authors declare no conflict of interest. 
International Journal of Advances in Scientific Research and Engineering (ijasre), Vol 7 (11), November -2021

\section{REFERENCES}

[1] Highland L, Bobrowsky P. The landslide handbook-A guide to understanding landslides. U.S. Department of the Interior. U.S. Geological Survey Circular 1325. 2008, 129p

[2] Gokceoglu C, Sezer E. A statistical assessment on international landslide literature (1945-2008). Landslides. 2009; 6 :345351. DOI 10.1007/s10346-009-0166-3

[3] Iverson MR. Landslide triggering by rain infiltration. Water resources research. 2000; 30(7): 1897- 1910. DOI 10.1029/2000WR900090

[4] Lee S, Hwang J, Park I. Application of data-driven evidential belief functions to landslide susceptibility mapping in Jinbu, Korea. Catena. 2012; 100: 15-30. DOI 10.1016/j.catena.2012.07.014

[5] Zahrul U, Biswajeet P, Anuar A, Jebur NM, Mahyat ST. Earthquake induced landslide susceptibility mapping using an integrated ensemble frequency ratio and logistic regression models in West Sumatera Province, Indonesia. Catena. 2014; 118:124-135. DOI 10.1016/j.catena.2014.02.005

[6] Liesbet J, Dewitte O, Poesen J, Delvaux D, Wim T, Kervyn M. The Rwenzori Mountains, a landslide-prone region? Landslides. 2015; DOI 10.1007/s10346-015-0582-5

[7] Wood JL, Harrison S, Turkington TAR, Reinhardt L. Landslides and synoptic weather trends in the European Alps. Climatic Change. 2016; 136:297-308. DOI 10.1007/s10584-016-1623-3

[8] Hong MH, Kim JH, Jeong SS. Rainfall intensity-duration thresholds for landslide prediction in South Korea by considering the effects of antecedent rainfall. Landslides. 2017; DOI 10.1007/s10346-017-0892-X

[9] Broeckx J, Maertens M, Isabirye M, Vanmaercke M, Namazzi B, Deckers J, Tamale J, Liesbet J, Wim T, Kervyn M, Vranken L, Poesen J. Landslide susceptibility and mobilization rates in the Mount Elgon region, Uganda. Landslides. 2018; DOI 10.1007/s10346-018-1085-y

[10] Monsieurs E. Modelling regional rainfall controls on landslide in the tropics in the context of climate change. Thèse de Doctorat, Université de Liège, Belgique. 2019.

[11] Ananta MSP, Kang HS, Lee JS, Kim YT. An ensemble landslide hazard model incorporating rainfall threshold for Mt. Umyeon, South Korea. Bulletin of Engineering Geology and the Environment. 2017; DOI 10.1007/s10064-017-1055-y

[12] Benineza GG, Rwabundandi I, Nyiransabimana MJ. Landslides hazards assessment using geographic information system and remote sensing: Gakenke District. Earth and Environmental science. 2019; (389) 012015. DOI 10.1088/1755$1315 / 389 / 1 / 012015$

[13] Corominas J, Van Westen C, Frattini P, Cascini L, Malet JP, Fotopoulou S, Catani F, Van Den Eeckhaut M, Mavrouli O, Agliardi F, Pitilakis K, Winter MG, Pastor M, Ferlisi S, Tofani V, Hervás J, Smith JT. Recommandations for the quantitative analysis of landslide risk. Bulletin of Engineering Geology and the Environment. 2014; 73: 209-263, DOI 10.1007/s10064-013-0538-8

[14] Knapen A, Kitutu MG, Poesen J, Breugelmans W, Deckers J, Muwanga A. Landslides in a densely populated county at the foot slopes of Mount Elgon (Uganda): Characteristics and causal factors. Geomorphology. 2006; 73:149 - 165. DOI 10.1016/j.geomorph.2005.07.004

[15] Sahani M. Le context urbain et climatique des risques hydrologiques de la ville de Butembo (Nord-Kivu/ RDC). Doctoral thesis, Université de Liège, Belgique. 2012 ; 300p

[16] Delvaux D, Mulumba JL, Sebagenzi SMN, Fiama BS, Kervyn F, Havenith HB. Seismic hazard assessment of the Kivu rift segment based on a new seismotectonic zonation model (western branch, East African Rift system). Journal of African Earth Sciences. 2017; 134: 831-855. 10.1016/j.jafrearsci.2016.10.004

[17] Wu X, Chen X, Zhan BF, Hong S. Global research trends in landslides during 1991-2014: a bibliometric analysis. Landslides. 2015; DOI 10.1007/s10346-015-0624-z

[18] Emmer A. Geographies and scientometrics of research on natural hazards. Geosciences. 2018; 8, 382. DOI 10.3390/geosciences8100382

[19] Bitar BJ, Mero CP, Burbano MN, Carballo MF. Rockfall research: A Bibliometric analysis and future trends. Geosciences. 2020; 10, 403. DOI 10.3390/geosciences 10100403

[20] Feng Z, Guo HC, Ho YS, Wu CZ. Scientometric analysis of geostatistics using multivariate methods. Scientometrics. 2007; 73 (3): 265-279. DOI: 10.1007/s11192-007-1798-5

[21] Heilig L, and Voß S. A Scientometric Analysis of Public Transport Research. Journal of Public Transportation. $2015 ; 18$ (2): 111- 141. DOI 10.5038/2375-0901.18.2.8

[22] Chaman SM, Kumar DP, Biradar BS. Remote Sensing Research in India: An Analysis of Publications output during 2011-2015. International Journal of Library and Information Studies. 2017; 7(4): 264- 271.

[23] Farideh O, Rouhallah K, Mansoor KR, Mansoureh SS. Co-authorship Network Structure Analysis of Iranian Researchers' scientific outputs from 1991 to 2013 based on the Social Science Citation Index (SSCI). COLLNET Journal of Scientometrics and Information Management. 2014; 8 (2):263-271. DOI 10.1080/09737766.2014.1015301 
[24] Li J, Zhang Y, Wang X, Ho YS. Bibliometric Analysis of Atmospheric Simulation Trends in Meteorology and Atmospheric Science Journals. Croatica Chemica Acta. 2009; 82 (3):695-705.

[25] Xie H, Zhang Y, Wu Z, Lv T. A Bibliometric analysis on land degradation: Current status, development, and future directions. Land. 2020; 9, 28. DOI 10.3390/land9010028

\section{Appendix 1: list of papers}

\begin{tabular}{llll}
\hline Authors & Title & Journal & Year \\
\hline Dille A, Kervyn F, Mugaruka & Causes and triggers of deep- & Geomorphology & 2019 \\
B, Delvaux D, Bamulezi GG, & seated hillslope instability in the & \\
Ilombe MG, Nakito SE, & tropics - Insights from a 60- & \\
Moeyersons J, Monsieurs E, & year record of Ikoma landslide & \\
Zolang C, Smets B, Kervyn M, & (DR Congo) & \\
Dewitte O. &
\end{tabular}

Moeyersons J, Tréfois $\mathrm{Ph}$, Lavreau J, Alimasi D, Badryo I, Mitima B, Mundala M, Munganga DO, Nahimana L.

Bunduki K, Mushayuma N, Tambala T, Materanya C, Matembera B.

Butara S, Fiama S, Mugisho BE, Mongane A.

Maki MJC, Dewitte O.

Mugaruka BT, Kulimushi MS, Muhindo SW, Dewitte O.

Kulimushi MS, Mugaruka BT, Muhindo SW, Michellier C, Dewitte O.

Nobile A, Dille A, Monsieurs E, Basimike J, Mugaruka BT, Oreye N, Kervyn F, Dewitte O.
A geomorphological assessment of landslide origin at Bukavu, Democratic Republic of the Congo

Cartographie des sites sinistrés par les glissements de terrain du 17 au 26/01/2014 dans le bassin du lac Kivu à Bukavu, SudKivu, RD Congo

Susceptibilité aux glissements de terrain : cas de la Commune d'Ibanda / Bukavu / République Démocratique du Congo

Engineering

2003

Geology

International

2015

Journal of

Innovation and

Scientific Research

International

2015

Journal of

Innovation and

Scientific Research

Vers un inventaire des glissements de terrain et des éléments à risque sur les versants du Rift à l'ouest du lac Kivu (RDC)

Glissement de terrain de Nyakavogo (Bukavu, RD Congo) : interaction entre facteurs naturels et anthropiques

Glissements de terrain et Geo-Eco-Trop éléments à risque dans le bassin versant de la Wesha (Bukavu, RD Congo)

Multi-Temporal DInSAR to Remote sensing 2018 2017

Geo-Eco-Trop

2017

2014

$$
\text { Geo-Eco-Trop }
$$

(1)

Characterise Landslide Ground Urban Environment: Focus on

Bukavu (DR Congo) 
International Journal of Advances in Scientific Research and Engineering (ijasre), Vol 7 (11), November -2021

Balegamire C, Michellier C, Muhigwa BJ, Delvaux D, Imani

$\mathrm{G}$, Dewitte O.

Kalikone BC, Teganya F, Dewitte O, Michellier C.

Tréfois $\mathrm{Ph}$, Moeyersons $\mathrm{J}$, Lavreau J, Alimasi D, Badryio I, Mitima B, Mundala M, Munganga DO, Nahimana L.

Moeyersons J, Tréfois $\mathrm{Ph}$ Nahimana L, Ilunga L, Vandecsteele I, Byizigiro V, Sadiki S.

Ilunga L,

\begin{abstract}
Vulnérabilité du bâti face aux glissements de terrain : analyse spatio-temporelle à Bukavu (RD Congo)
\end{abstract}

Geo-Eco-Trop

2017

Impact des déformations du sol

Geo-Eco-Trop

2017 sur la vulnérabilité des réseaux de distribution d'eau et d'électricité à Bukavu (RD Congo)

Geomorphology and urban geology of Bukavu (R.D. Congo) : interaction between slope instability and human settlement

River and landslide dynamics on the western Tanganyika rift border, Uvira, D.R. Congo : diachronic observations and a GIS inventory of traces of extreme geomorphologic activity

Etude des sites majeurs Geo-Eco-Trop d'érosion à Uvira (R.D. Congo)
Natural Hazards 2009

Geological Society

2007

(1)

2006

*Corresponding author: Ngulwe Tumaini wa Rusaati, E-mail: rusaati@gmail.com 